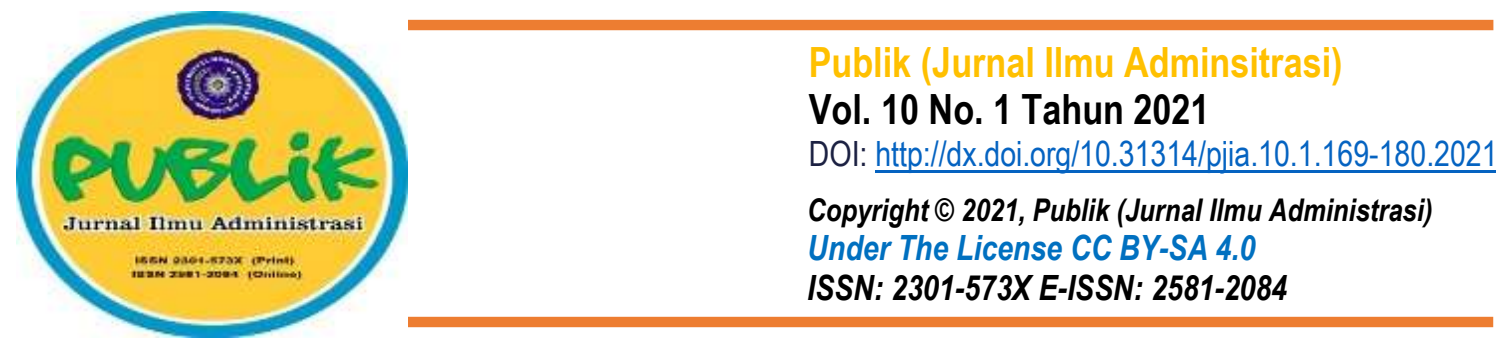

\title{
The Difference of Political Participation of Inland Communities and Coastal Communities in Responding to Local Election: Synergy in Combating Covid-19 and Money Politics
}

\author{
Asna Aneta ${ }^{*}$, Abdul Wahab Podungge ${ }^{2}$, Robby Hunawa ${ }^{3}$, Muten Nuna ${ }^{4}$ \\ $1^{\star}$ Universitas Negeri Gorontalo, Indonesia \\ 123 Universitas Gorontalo, Indonesia \\ Email: asnaatiek.aneta@ung.ac.id , podunggewahab@gmail.com , robbyhunawa86@gmail.com , \\ mutensnuna@gmail.com
}

Abstract This study is aimed at analyzing the difference in political participation of inland communities and coastal communities in addressing local elections as an embodiment of synergy in combating Covid-19 and money politics. In this qualitative research, the data were analyzed using an interactive model comprising three analysis components: (1) data reduction, (2) data display, and (3) data verification and conclusion drawing. According to the results, the way the coastal communities respond to the local election differs from that of the inland communities regarding sociological perspective. The coastal communities are not so keen on the election as they concentrate more on their fishing activities. On top of that, people in coastal areas spend most of their time at sea; thus, issues regarding the election are not that impactful for them. The inland communities, on the other hand, has different views thanks to their gregarious characteristic. All their activities and work-life are centralized in a workgroup, enabling the people to have ample time to find out their local leader candidates. This aspect underlines the reason for pluralism among inland communities' political views, confirming the characteristic of individualism among people in coastal areas.

Keywords: Political Participation; Society; Local Elections

\section{Received:23-05-2021 Revised:27-05-2021 Accepted:08-06-2021}

\section{INTRODUCTION}

Political participation, the embodiment of population sovereignty, is fundamental in democracy. High participation of society marks an unequivocal way to better political progress and democracy in Indonesia. The actualization of democracy at a local level is seen in, for example, the simultaneous regional election of Bone Bolango Regency back in 9 December 2020. Democracy is not always perfect considering some polemics in the involvement of the society that contributes to the process of regional elections. Among the example is differing perspectives between the coastal community and inland community. The two group has its distinct traits and views on the election in Bone Bolango Regency. 
The present paper discusses the differences in the perspectives of inland communities and coastal communities in Bone Bolango Regency regarding the past local election on 9 December 2020. Coastal communities see politics as transactional, hindering the political participants explain their visions and missions since the people expect "the incentives" from the candidates i exchange for votes. On the contrary, inland communities that are dominated by people working at agricultural sectors show respect to the leader candidates. This is seen from their enthusiasm in understanding the proposals of the political participants.

Central to the political life of communities is the involvement of voters or the voters' behavior. Political democracy and socio-cultural diversities are impactful on the growth and development of democracy. Fauzi, AM (2019) opines that "there are times when people are unconcerned of the issues of elections as reflected in the New Order election, which is known for its complex problems. At the time, the vote was intervened by some parties. The intervention of the vote was also influenced by the issues of money politics; still, full involvement of a voter and the awareness of the leader candidate still existed during the election.

It is worth noting that socioeconomic status affects the way individuals respond to elections, as seen in a study by Mery A (2018) claiming that socioeconomic status, educational background, income, and high-paying jobs result in fair participation and involvement of society without indication of money politic. Conversely, money politics associate with poor educational background, low income, and blue-collar workers. Hatu R (2011) argues that changes in socio-cultural aspects do not revolve around urban life but also inland life. However, it is important to note that people living in inland areas lack technology exposure, including access to better communication, transportation, and social order. Inland communities are used to be a social group upholding the principles of solidarity and unity. The advancement of technology in almost every aspect has brought a shift in cultural values, thus degrading the unity among society members, turning people into individualists.

Bone Bolango Regency is geographically dynamics due to its varied geography; the regency has inland, urban, and coastal areas. Despite the restriction amidst the Covid-19 pandemic, deceptive election practices, such as money politics, still lay ahead. The condition has been a challenge for the committee of the election and leader candidates to bring a shift in people's perspectives on the negative impact of money politics. The possibility of electoral fraud blames the economic condition of the people living in the coastal and inland areas since their income fluctuates. Fishers may earn more during the fishing season, but the situation is temporary as when the climate becomes unfriendly, the fishers do not gain profit. To worsen, the fishers need to deal with relatively 
high operational costs. A similar condition applies to the inland communities where its population primarily works as farmers or miners since their income depends on certain seasons and climates.

In the present work, a preliminary review was performed at five selected coastal areas of Bone Bolango Regency: Bone District, Kabila Bone District, Bone Pantai District, Bulawa District, and Bone Raya District. For the inland areas, the districts involve Suwawa Tengah District and Pinogu District. The majority of the area in the two districts is 100 to 500 meters above sea level, thus confirming that Suwawa and Pinogu District are in remote areas, located between the highlands surrounding Bone Bolango Regency. Pinogu District is the hardest area to reach from the city center as the district is quite isolated. Thereby, Pinogu is on the list of 29 disadvantaged areas. In comparison, 131 villages in 18 districts within Bone Bolango Regency have been in the category of developing areas.

The preliminary review results revealed that some people in the areas mentioned previously have a low understanding of politics, especially information regarding the Local Election of Bone Bolango Regency 2020. Some people even admitted that they would receive money or essential goods if they vote for a specific candidate. What makes the situation worse is that most of the population are only junior high or senior high graduates. Law Number 7 of 2017 Concerning Elections clearly states that the election management bodies, involving General Election Commission, Election Supervisory Body, and the Election Management Bodies' Ethics Council shall work collaboratively and synchronously for fair and just elections. This notion without question delineates that the bodies should prevent frauds committed either by the candidates or voters. This includes combatting money politics and the paradigm that such dishonest practice is normal and has no impact on democracy in Indonesia, particularly Bone Bolango Regency.

The Simultaneous Local Elections in 2020 were different from the previous ones due to the Covid-19 pandemic. Amidst the pandemic, more people become unemployed, thus escalating the likelihood of fraud, i.e., money politics, in the election on 9 December 2020. Combatting such electoral frauds is the duty of the election bodies. The data revealed seven districts under the category of inland and coastal areas with a total of 35,280 voters and 1,402 young voters. With that in mind, practices of money politics are inevitable.

In combatting electoral frauds, such as money politics, the election bodies and supervisory staff are urged to maximize their performance. They should look beyond regulations and create a breakthrough in dealing with reports regarding such misconduct, particularly during the silence period and during the election day. Such countermeasure is crucial since some of the voters in the coastal areas have no problem with "incentivization", making them prone to money politics. From 
the above discussion, the present work is devoted to exploring factors behind money politic practices in the regional election of Bone Bolango Regency. This study also addresses the reasons why the voters in the research sites are lured into such transactional politics.

\section{METHODS}

This study employed qualitative research since no hypotheses were required to be proven and/or rejected prior to the study. Further, the data were analyzed non-numerically. The qualitative method is applied for testing hypotheses or theories. The qualitative approach was selected to have in-depth analysis regarding the different views between inland communities and coastal communities--why people living in inlands are more social compared to their neighbors in the coastal areas that are susceptible to money politics.

Informant selection was done using the purposive sampling technique. Informants are needed to obtain data related to this study; thus, they should have a deep understanding of the current topic. The informants were those in the final voter list (DPT) in the 2020 Local Leaders Election (Pilkada) of Bone Bolango Regency. The informants were from seven districts, namely districts of Bone, Kabila Bone, Bone Pantai, Bulawa, Suwawa Tengah, Pinogu, and Bone Raya.

The observation was employed as the data collection technique in order to observe the cultural conditions of inland and coastal communities in the Bone Bolango Regency. Furthermore, key informants, who are the people included in the final voter list spread over seven districts in the coastal and inland areas of Bone Bolango Regency, were interviewed. The data analysis steps involved data collection, data reduction, data display, and verification (Miles, Matthew, \& A, 1992)

\section{RESULTS AND DISCUSSION}

The GMF, Bone Bolango Regency is one of six regencies within the Gorontalo Province with $1,984.31 \mathrm{Km} 2$. Approximately $48.65 \%$ of its area is located at 100-500 meters above sea level. Geographically, the area of Bone Bolango Regency is in the north directly bordered by Gorontalo Utara Regency, east by Bolmong Selatan Regency, in the west by Gorontalo City and Gorontalo Regency. In the Bone Bolango Regency, two watershed management area units (SWP DAS), namely the watershed of Bone and Bolango, lead to Gorontalo City. The Bone watershed is the largest and has the largest forest area in Bone Bolango Regency compared to the Bolango watershed.

Based on the results, the informant in the coastal area, who is included in the final voter list, stated: I think the people's political participation in the coastal area is not good enough. This can 
be seen from the public's lack of enthusiasm in participating in the campaigns of the candidates, and most of the candidates tend to meet the citizen only due to the political event, and the number declines after a while, especially fishers." Therefore, it is safe to assume that there are differences in the characteristics of coastal and inland communities in viewing the democratic party for the local election. Inland communities are more focused on meeting their daily needs, such as working in gardens, fields, and traditional mining, rather than being enthusiastic about campaigning for local head candidates. Meanwhile, coastal communities that generally work as fishers prioritized marine activities and the sale of catches rather than participating in the election of local heads. Ramlan Subakti (1992) classifies political participation into two parts: 1) Active participation, an activityoriented to political input and output. Active participation includes submitting proposals on public policies, proposing alternative public policies that are different from the policies made by the government, submitting criticisms and improvements to straighten policies, paying taxes, and electing government leaders; 2) Passive participation which is an activity that is oriented towards results or outputs. Activities that include passive participation are activities that obey the government, accept, implement every government decision.

Furthermore, based on the interview with another informant who is also on the final voter list in the 2020 Bone Bolango Regency Election, they stated, "to be honest, sir, rather than being busy participating in the campaign, they would have known what we needed was meals for our stomach. So, we are better off waiting for the dawn attack before election day instead of being actively involved in the democratic party. We also work as fishers, usually four days to 1 week at sea, so when we land, we only need to rest for a day or two while repairing the boat and the operational needs of fishers at sea. There is not much time left for activities to listen to the vision and mission of the candidate for Regent". Based on interviews, it is presumed that the factors that influence political participation are social and economic status. Social status is a person's position in society because of heredity, education, and work.

Meanwhile, economic status is a person's position in society based on financial income. Someone who has a high social status is estimated not only to have political knowledge but also to have an interest and concern for politics (Ramlan Subakti, 1998). Communities' participation at the moment of the local leaders' election, especially coastal and inland communities, is not only seen from the number of voters' attendance using their voting rights at the polling place but measured by public awareness and active involvement in all stages by the election organizers. Participation aims to encourage democratic activities for all electoral processes actively. The importance of focusing on participation is an indicator of improving the quality of democracy and the nation's 
political life. Therefore, it is hoped that the political involvement of the coastal and inland residents should not be underestimated, whether in formal and extra-formal forms of participation in supervising the implementation of the election. This is due to its existence that might prevent counter-democratic actions that might have the ability to shake and degrade people's loyalty to the democratic system in Indonesia. In addition, for local head candidates, amid the Covid-19 pandemic, campaign euphoria should not be excessive and prioritize innovation in online campaigning so as not to create crowds during communities' groups.

Furthermore, local head candidates should comply with the Covid-19 health protocol in campaigning and avoid the potential for money politics. Money politics occurs because of the strong perception that the local leaders' election is a celebration, short-term pragmatism culture, weak dialectics to seek ideal values and build a shared vision, weak rules of the game, et cetera. Furthermore, Mashudi (2015) proclaims that "The opportunity in creating money politics starts from the communities itself. When the communities have the integrity that money politics will only bring damage to the democratic climate, then there will be no chance for the candidate for local head to influence and confirm the distribution of money before the election takes place.

Dendy Lukmajati (2016) further adds that "Healthy elections are fair, open and without any pressure politically or psychologically from other individuals. It is necessary to know that sometimes elections are treated as festivities by capital owners to revel in attaining the status of authority by influencing the voters, which in this case are the society, with varying ways such as bribery and rewards, or political and even physical pressures at some point and certain times."

Society is a group of humans that socialize and interact with each other. This interactive unity of lives is based on a continuous system and is bound together by an identity (Effendi, 2010). This idea is comprehended in social characteristics of the coastal community, especially fisherman and inland communities, such as farmers, as the concept of the society itself. In order to differentiate characteristics of inland and coastal community in participating in Bone Bolango Local Election 2020 along with the threat of money politic and Covid-19 pandemic, the data of poor households in Bone Bolango Regency, which spans seven districts, are presented as the focus of this article.

Based on the data in Table 1, it is clear that the poor household in seven districts is categorized in the high defect. It is believed that this was due to the fact that the coastal and inland community means of livelihood in Bone Bolango are not fixed incomes. Most of these households are poor based on the previous data from the social service. 
Table 1

The Poor Household in Seven Districts in Gorontalo

\begin{tabular}{|c|c|c|c|c|c|c|}
\hline \multirow[t]{2}{*}{ No } & \multirow[t]{2}{*}{ District } & \multicolumn{4}{|l|}{ Cluster } & \multirow[t]{2}{*}{ Total } \\
\hline & & Decile 1 & Decile 2 & Decile 3 & Decile 4 & \\
\hline 1 & Bone & 933 & 99 & 93 & 83 & 1.208 \\
\hline 2 & Bone Raya & 257 & 28 & 25 & 41 & 351 \\
\hline 3 & Bone Pantai & 954 & 77 & 107 & 103 & 1.241 \\
\hline 4 & Bulawa & 309 & 30 & 34 & 41 & 414 \\
\hline 5 & Kabila Bone & 917 & 58 & 66 & 70 & 1.111 \\
\hline 6 & Suwawa Tengah & 255 & 49 & 59 & 70 & 433 \\
\hline 7 & Pinogu & 312 & 32 & 26 & 21 & 391 \\
\hline \multicolumn{2}{|c|}{ Total } & & & & & 5149 \\
\hline
\end{tabular}

Data Source: Social Service of Bone Bolango Regency, 2019.

Table 2

Regarding Voters in Seven Districts Within the Coastal Areas and Inland of Bone Bolango Regency.

\begin{tabular}{|c|c|c|c|c|c|}
\hline \multirow{2}{*}{$\begin{array}{l}\text { Districts in coastal and } \\
\text { inland areas of Bone } \\
\text { Bolango Regency }\end{array}$} & \multirow{2}{*}{$\begin{array}{c}\text { Number of } \\
\text { polling stations }\end{array}$} & \multicolumn{3}{|c|}{ Number of voters } & \multirow{2}{*}{$\begin{array}{l}\text { Young } \\
\text { voters }\end{array}$} \\
\hline & & Male & Female & Total & \\
\hline Bone District (Coastal) & 19 & 3,322 & 3,031 & 6,228 & 241 \\
\hline $\begin{array}{l}\text { Bone Pantai District } \\
\text { (Coastal) }\end{array}$ & 15 & 3,767 & 3,613 & 7,380 & 310 \\
\hline $\begin{array}{c}\text { Bone Raya District } \\
\text { (Coastal) }\end{array}$ & 10 & 2,330 & 2,247 & 4,577 & 181 \\
\hline $\begin{array}{l}\text { Bulawa District } \\
\text { (Coastal) }\end{array}$ & 9 & 1,752 & 1,673 & 3,425 & 149 \\
\hline Kabila Bone (Coastal) & 18 & 3,983 & 3,835 & 7,818 & 293 \\
\hline $\begin{array}{l}\text { Suwawa Tengah } \\
\text { District (Inland) }\end{array}$ & 12 & 2,187 & 2,156 & 4,343 & 167 \\
\hline Pinogu District (Inland) & 5 & 744 & 655 & 1,409 & 61 \\
\hline Sum Total & 88 & 18,085 & 17,210 & 35,280 & 1,402 \\
\hline
\end{tabular}

Source: General Elections Commission, Bone Bolango Regency 2020

According to the above table, there are 36,682 voters in 88 polling stations spread over the coastal and rural areas of Bone Bolango Regency. An interview with 40 randomly selected voters was also conducted during the preliminary observation; they are from seven districts in the coastal areas. The interview reported that most of the voters have no issues with "the incentives" they received from the candidates. Only $7 \%$ of the voters who vote according to their conscience, and 
the remaining $8 \%$ decided to abstain despite receiving "the incentives." The $65 \%$ and $8 \%$ voters argue that 1) rejecting gifts is not permissible; 2) the people believe in the old saying "what is meant to be will always be"; 3) the incentive is a form of returning one's a favor; 4) there is a guilty feeling if they decide to abstain after receiving "the incentive"; 5) "the incentive" is the reimbursement of transportation fee and work payload since 6) going to the poll station is not cheap and 7) they have to leave their work during the election; 8) the voters did not know the person they are going to vote, something that really matters for them are "the incentive"; 9) the voters do not really care about politic as they deemed it has not significance to their fulfilment of essentials. Based on the interview results with the informants as well as some data and statements from experts in the article, the following are several assertions regarding the cause of money politics in local head elections.

\section{Economic Limitations}

Money politics in coastal and inland communities are synonymous with economic limitations, which was always the cause of problems for the election committee nowadays. Money politic in the society is made possible from the poverty factor, where the coastal and inland communities are to think rationally and temporarily in gaining profit that is incomparable by receiving rewards from the election contestants. This means that money politics will not be easy to prevent or terminate if the economic limitations and poverty still plague the coastal and inland communities.

\section{Poor Education}

The poor educational quality of the coastal and inland community in Bone Bolango is related to economic limitations, which leads to most of the society members being unable to get access to higher education. This affects their ideology and behavior in taking actions and making decisions. Poor educational quality will ultimately cause the society to possess insufficient knowledge regarding politics and sanctions in local head elections. The society's unawareness of this problem affects their behavior in terms of the occurring money politic, shown by how easy the society accepts a certain number of rewards to be easily manipulated by particular parties in the election a contestant from the election. Further, pragmatical behavior within the society allowed them to ignore violations, which would lead to poor political awareness and participation.

\section{Poor supervision}

Money politic is also challenging to exterminate if the cooperation between the community and election committee has minor supervision, especially approaching the election day. Despite having authorities prevent money politics, the regency (General Election Supervisory Body) has no right to act upon the money politic violation. Based on Law Number 7 of 2017 Article 103a, the 
General Election Supervisory Body only has the authority to take, and follow-up reports related to alleged violations on the implementation of laws that constitute an election. In contrast, the money politic process is under the criminal law domain in violation of election, which must be resolved by judges' decision (Metria Shela and Sutiyo, 2018). The poor surveillance emphasizes the individual adaptation on rules that oversees the money politic itself. Poor education also affects society's ideology with no proper comprehension and internalization regarding the supervising rules to prevent money politic among society.

\section{Habits and Traditions}

Money politic among the society will continue if it is left unchecked, which would be caused by poor surveillance, cooperation, knowledge, and awareness of the society. The analysis results on the characteristics of inland and coastal community in interpret the election found several differences, in which the coastal community tends to be individualistic and refuse to be influenced by urban issues. They are not quick with adaptations which implied the process of determining behaviors on the political candidate pair also depends mainly on the local government head candidate or supporters who will provide them rewards, whereas the inland communities are more clustered and take action in unison upon the candidate pair. It is believed that this is the effect of the inland environment with cooperative habits such as farmers, gardeners, and fishers who lived in the same working environment and have an emotional bond with each other. The coastal community is also affected by their environments where the fishers' daily life was spent with their family or fixing their rods and nets if they are not working, becoming less social with nearby society and other social environments. They only focus on profitable activities and especially incomes; this type of tradition and habits became an inherited culture among the inland and coastal community.

\section{Contributing Factors of Money Politic}

The money politic takes many forms, both directly and indirectly, by other parties such as supporters involved in money politics. The process of money politic used strategies to manipulate and mobilize the society from varying modus operandi, a form of rewards, to time and place to execute money politic which was considered carefully with specific stages in a particular set of time to ensure the success of a candidate pair in winning the election. Contributing factors of money politics involve the mutual relationship between the perpetrators, i.e., political parties, politicians, or other stakeholders, and the targets, i.e., voters. For politicians, money politics are an instant way to gain votes, while the voters consider this act as a bonus they will receive in a specific period (compared to election promises that often are not put into action). Simply put, society considers money politics as the only mechanism that they can benefit much from for their involvement in the 
election. Such practices, however, should be prevented during the Local Election of Bone Bolango Regency in 2020. On that ground, the supervisory bodies are urged to go the extra mile to promote people's awareness regarding the negative impact of money politics. Podungge, A. W. and Aneta, A (2020) claim that professionalism attitudes can serve as an approach to addressing the issues of money politics, resulting in better democracy in Indonesia.

Unlike other people, young voters see political participation differently. This notion corresponds to the results seen in Wardhani, P. S. N. (2018) claiming that political participations of young voters are distinctive; however, almost all young voters are aware of their contribution to politics and their right to vote, demonstrating good citizenship. Still, some factors can hinder them to actively participate in the election, such as being busy and insecure, and family influence.

\section{CONCLUSIONS}

This study concludes that inland communities see politics differently from their coastal counterparts in terms of the political decisions. People living in coastal areas tend to be individualist in participating in regional elections. On the contrary, a strong sense of unity determines the political participation of people in rural areas. Money politics is detrimental to the democracy in Bone Bolango Regency. Taking no countermeasures will only trigger new problems that can harm the perspective of the people, their welfare, and the progress of the region and country in the coming days. The selected leader, in the coming five-year of their term, (if their vote is due to "the incentive"), are expected to recover their "investment", resulting in poor performance as the leader prioritize the interest of the success team and other parties contributed to his/her victory. Active involvement of the election bodies, including General Election Commission, Election Supervisory Body, and the Election Management Bodies' Ethics Council are necessary to fight all frauds in election (this also covers taking any measures from the campaign period to the election day). Holding elections amidst the Covid-19 pandemic is a lot harder than in normal situation, because frauds are more likely to happen.

\section{REFERENCES}

Budiardjo, M. (2008). Dasar-Dasar Ilmu Politik. Jakarta: Gramedia Pustaka Utama.

Dewi, A. A. I. A. A. (2018). Model Pengelolaan Wilayah Pesisir Berbasis Masyarakat: Community Based Development. Jurnal Penelitian Hukum P-ISSN, 1410, 5632. DOI: Http://Dx.Doi.Org/10.30641/Dejure.2018.V18.163-182

Effendy (2010) Komunikasi Teori Dan Praktek. Jakarta: PT Grasindo. Rosdakarya. 
Fatwa, A. N. (2016). Pengaruh Kesadaran Politik Terhadap Partisipasi Politik Masyarakat Dalam Pemilihan Bupati Tahun 2013 Didesa Sesulu Kabupaten Penajam Paser Utara. Ejournal IImu Pemerintahan, 4(4), 1615-1626.

Fauzi, A. M. (2019). Perilaku Pemilih Menjelang Pemilu 2019. Journal Of Islamic Civilization, 1(1), 40-48.

Hatu, R. (2011). Perubahan Sosial Kultural Masyarakat Pedesaan (Suatu Tinjauan TeoritikEmpirik). Jurnal Inovasi, 8(04).

Lukmajati, D. (2016). Praktek Politik Uang Dalam Pemilu Legislatif 2014 (Studi Kasus Di Kabupaten Blora). Politika: Jurnal IImu Politik, 7(1), 138-159.

Mery, A. (2018). Hubungan Status Sosial Ekonomi, Kesadaran Politik, Kepercayaan Terhadap Sistem Pemerintahan Dan Politik Uang Dengan Partisipasi Politik Masyarakat Kabupaten Dharmasraya Pada Pilkada Serentak 2015 (Doctoral Dissertation, Universitas Andalas).

Miles, Matthew, B., \& A, M. H. (1992). Analisis Data Kualitatif. Jakarta: Universitas Indonesia Press. Podungge, A. W., \& Aneta, A. (2020). Profesionalisme Pegawai Ditinjau Dari Aspek Pengorganisasian Dalam Pelayanan Publik. Publik (Jurnal IImu Administrasi), 9(1), 55-65. DOI : http://dx.doi.org/10.31314/pjia.9.1.55-65.2020

Syatori, A. (2016). Ekologi Politik Masyarakat Pesisir (Analisis Sosiologis Kehidupan SosialEkonomi Dan Keagamaan Masyarakat Nelayan Desa Citemu Cirebon). Holistik, 15(2).

Saleh, K., \& Munif, A. (2015). Membangun Karakter Budaya Politik Dalam Berdemokrasi. Addin, 9(2).

Shela, M., \& Sutiyo, S. (2018). Peran Bawaslu Dalam Mencegah Money Politics Dalam Pemlihan Gubernur Provinsi Lampung Tahun 2018. Wacana Publik, 12(02).

Surbakti, R. (1992). Memahami Ilmu Politik. Jakarta : Grasindo.

Tyas, F. S. (2014). Peran Orang Tua Dalam Menanamkan Kesadaran Politik Pada Anaknya Sebagai Pemilih Pemula Di Kelurahan Tambakrejo Kecamatan Simokerto Surabaya. Kajian Moral Dan Kewarganegaraan, 1(2), 273-289.

Torere, W., Goni, S. Y., \& Waani, F. J. (2019). Peran Ganda Istri Nelayan Pada Masyarakat Pesisir Di Desa Kima Bajo Kecamatan Wori Kabupaten Minahasa Utara. HOLISTIK, Journal Of Social And Culture

Undang-Undang Nomor 7 Tahun 2017 Tentang Pemilu

Umar, M. (2015). Money Politic Dalam Pemilu Perspektif Hukum Islam (Studi Analisis Keputusan Lembaga Bahtsul Masail Nahdlatul Ulama). At-Turas: Jurnal Studi Keislaman, 2(1). 
Wardhani, P. S. N. (2018). Partisipasi Politik Pemilih Pemula dalam Pemilihan Umum. Jupiis: Jurnal Pendidikan IImu-IImu Sosial, 10(1), 57-62. 